\title{
Synecological Map of the University of British Columbia Research Forest ${ }^{1}$
}

Karel Klinka

B.C. Forest Service, 355 Burrard Street, Vancouver, B.C. V6C $2 \mathrm{H} 1$

\section{Lou Skoda}

Canadian Cartographics Limited, 508 Clarke Road, Coquitlam, B.C. V3J 3C2

\begin{abstract}
A synecological map on a 5,150 ha area of the U.B.C. Research Forest, Haney, B.C., was prepared at the scale $1: 10,000$. Forest ecosystems (biogeocoenoses) were classified through synthesis of similar plots, following the analysis of vegetation by the phytosociological techniques of the Zürich-Montpellier School and of corresponding habitats as adapted by Krajina and his students. The mapping was done by a combination of ground survey and aerial photographic interpretation. The thrust of the cartographic design for the map focused on criteria appropriate to map series. Aspects of format, information content and of color design, are illustrated and discussed.
\end{abstract}

\section{Résumé}

On a préparé, à l'échelle de 1:10,000, une carte synécologique couvrant 5,150 ha de la forêt expérimentale de I'Université de la Colombie britannique à Haney. On a classifié les écosystèmes (ou biogéocénoses) en faisant la synthèse de placettes-échantillons et des habitats correspondants, analysées selon la méthode phytosociologique de l'Ecole de Zürich-Montpellier telle qu'adaptée par Krajina et ses disciples.

La mise en plan a été réalisée en combinant les observations terrestres à la photointerprétation, et on a choisi la méthode cartographique en fonction de l'échelle utilisée. La discussion porte sur le format de la carte, sur son contenu, et sur l'utilisation des couleurs.

\section{Introduction}

The objective of this paper is to present a synecological map of the U.B.C. Research Forest with a brief outline of approach, methods and design.

The presented material is based on a portion of a detailed synecological study carried out in the Forest by Klinka (1976) under the guidance of Dr. P.G. Haddock and Dr. D.S. Lacate, Faculty of Forestry, and Dr. V.J. Krajina, Department of Botany, University of British Columbia. This study is being prepared for publication in Syesis (published by the British Columbia Provincial Museum). The aim of the study was to complete the classification of forest ecosystems initiated by Lesko (1961) and Orloci $(1961,1964,1965)$, to propose interpretations for ecosystematic units for management purposes and to provide a synecological map for the Forest. The synecological map is a corollary to a map of land units prepared by Lacate (1965) for the same area.

\footnotetext{
${ }^{1} \mathrm{~A}$ copy of the map can be obtained from Mr. J. Walters, Director of the University of British Columbia Research Forest, R.R. 2 Maple Ridge, B.C. V2X 7E7.
}

The term ecosystem is well understood as a functional entity, including both organisms and their environment each influencing the other. However, this interpretation is too broad and the term lacks a definitive level. Such broad concepts may lead to inconsistencies when defining an ecosystem as the object of study or for practical purposes. There is a need for a clearly defined and recognizable ecosystem because different concepts would lead to different classifications. For the forest ecosystem, in addition to other components, includes both vegetation and soil, it follows that the concept of an ecosystem individual must accommodate requirements laid out for both polypedon and plant community. Biogeocoenosis (Sukachev 1944) is considered to be a concrete expression of an ecosystem individual. It represents a certain habitat (polypedon) which is manifested by a certain plant community (Table 1).

\section{Methods}

Methods employed are those used by Krajina and his students described recently by Brooke et al. (1970) and Kojima and Krajina (1975). One hundred and fifty-eight sample plots were established in the Forest, each plot representing a sample of an ecosystem individual-biogeocoenosis. Folloying an analysis of the vegetation and its environment, a synthesis of similar plots into abstract units is carried out. The biogeocoenoses are classified according to the classification system proposed by Krajina (1972). Then they are floristically and environmentally characterized with an emphasis on vegetation-environment relationships, and environmental factors and processes controlling their distribution and development. The classification is verified by additional investigations to substantiate ecological significance of the differentiated units.

As a result of species poor flora in British Columbia, we find that different soils may develop a similar vegetation (i.e. they support similar plant communities), providing their total climatic and edaphic (moisture and nutrient) effect is similar. Therefore, each type of biogeocoenosis, more specifically forest ecosystem type (the term proposed for the operational use), must be designated not only by its vegetation component but also by its soil component (Table 2). 
Table 1

Relationships Between Sampling Units, Natural Bodies and Basic Taxa in the Soil, Vegetation and Synecological Classification

\begin{tabular}{llll}
\hline \multicolumn{1}{c}{ Fundamental Units } & \multicolumn{1}{c}{$\begin{array}{c}\text { Soil } \\
\text { Classification }\end{array}$} & Vegetation Classification & Synecological Classification \\
\hline \hline Basic taxon in the classification system & Soil Series & $\begin{array}{l}\text { Plant Association (and its lower } \\
\text { units: (sub association and } \\
\text { variant) }\end{array}$ & $\begin{array}{l}\text { Type of Biogeocoenosis (forest } \\
\text { ecosystem type) }\end{array}$ \\
\hline Natural body (individual) & Polypedon & Plant Community & Biogeocoenosis (basic ecosystem) \\
\hline Sampling unit (minimal size of an individual) & Pedon & $\begin{array}{l}\text { Sample Plot (stand, association } \\
\text { individual) }\end{array}$ & Sample Plot (including pedons) \\
\hline
\end{tabular}

Table 2

Plant Association and Its Associated Soils

\begin{tabular}{|c|c|}
\hline \multicolumn{2}{|c|}{ Forest Ecosystem Types } \\
\hline Plant Association & Soil Units (Polypedons) \\
\hline GAULTHERIA (SH.) $-P M^{1}$ & $\begin{array}{l}\text { 1. on loamy sand Lithic Mini } \\
\text { Humo-Ferric Podzol with } \\
\text { moder humus, developed on } \\
\text { moraine veneer } \\
\text { 2. on sandy loam Lithic Podzol } \\
\text { with F-mor humus, develop- } \\
\text { ed on moraine veneer } \\
\text { 3. on Lithic Folisol with F-mor } \\
\text { humus, developed from or- } \\
\text { ganic veneer } \\
\text { on sandy loam Mini Humo- } \\
\text { Ferric Podzol with F-mor } \\
\text { humus, developed on mo- } \\
\text { raine blanket } \\
\text { on sandy loam Mini-Humo- } \\
\text { Ferric Podzol with moder } \\
\text { humus, developed on glacio- } \\
\text { fluvialdeposits } \\
\text { 6. on loamy sand Mini and } \\
\text { Orthic Humo-Ferric Podzols } \\
\text { with F-mor humus, develop- } \\
\text { ed on colluvial veneer }\end{array}$ \\
\hline
\end{tabular}

${ }^{1}$ Abbreviated Latin name; the full Latin of this plant association is as follows: Stokesiello (oreganae) - Hylocomio (spendentis) - Gaultherio (shallonis) - Pseudotsugetum menziesii.

\section{Mapping}

The objectives of synecological mapping were to demonstrate its feasibility and to prepare a design for a synecological map series.

The scale $1: 10,000$ and desire to provide fairly homogeneous stratification with regard to climate, soil and vegetation were behind the selection of biogeocoenotic units (plant association, forest ecosystem type) as mapping units. These units represent certain limited habitats, distinctly differentiated from any other, sometimes transitionally connected with the neighbouring ones through some gradients, sometimes abruptly separated, when gradients are lacking. Their habitats can be characterized by a combination of a respective plant community and the associated soil. The plant community which tree species are able to perpetuate under the forest canopy is used as a benchmark vegetation component. The associated soils (polypedons) correspond to a soil series, although soil series per se were not defined. However, the majority of forest ecosystem types, despite the detailed scale, could not be separated by boundaries, due to a great variability of soil. Therefore, a number of mapping units were established to fit the scale to the distribution of biogeocoenoses in the landscape. The mapping units (complexes) were defined in terms of usually two or three closely related forest ecosystem types which are intimately associated geographically.

The mapping involves the identification of biogeocoenoses through their typified vegetation and soils and outlining their boundaries. Similarly as in soil mapping, a mapper predicts that the delineated areas will have the same properties as those, limited in their extent, where both external and internal properties were sampled and measured. The predictions are based on correlations between external and internal sets of properties, which repeat in the landscape within the limits of a kind of macroclimate (biogeocli. matic subzone) and soil parent materials.

The mapping was done by a combination of ground survey and aerial photographic interpretation, using black and white, color and color infrared imagery. Most of the boundaries were seen in the field, the rest was located on photographs and field checked. The ground mapping was carried out at the rate of 50 to 100 ha per day. When using aerial photographic interpretation, the mapping performance could be increased up to 1,000 ha per day.

\section{Synecological map}

A synecological map shows where forest biogeocoenoses occur in relation to each other and to other landscape features (Fig. 1). Its potential application becomes self-evident when the map is related to interpretations prepared for the taxonomic units.

Numerical symbols designate mapping units. The first part of the symbol may contain up to three digits. The first digit refers to a plant alliance, the second digit to plant association and the third digit to plant subassociation. The second part of the symbol refers to soil parent materials, using genetic categories of landform classification. It may contain up to two digits, indicating in this case lithological discontinuity or complexity of materials in the landscape. The complete symbol identifies fully the soil component and hence the forest ecosystem type (Fig. 2). 


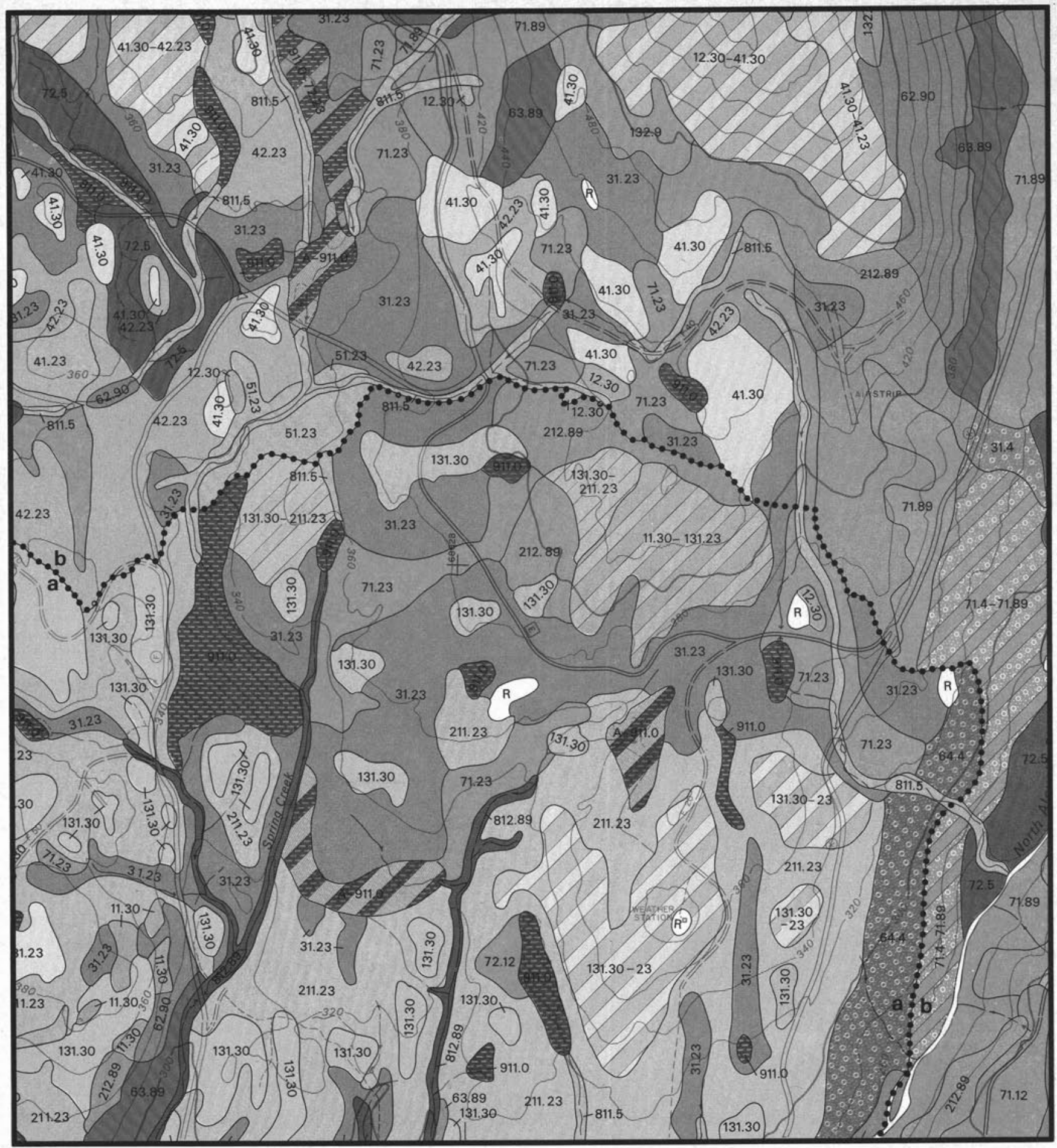

Fig. 1. A part of the synecological map of the U.B.C. Research Forest.

The cartographic design focused on two broad aspects of presentation-color and format.

The color scheme developed for the map defines each biogeocoenotic unit within a two-dimensional color space. In this space wavelength (hue) is assigned to represent soil moisture regime while the soil nutrient regime is represented by color saturation (chroma) as it is designated in the Munsell color terminology.

As shown in Figure 2, very xeric soil moisture regime is represented by a red hue (about 650 $\mathrm{m} \mu$ ). From this point, the scale progresses through red-yellow, yellow, yellow-green, green,

blue-green and blue to the subhydric regime which is represented by purple-blue. This final hue is a non-spectral color close to the short wavelength end of the visible spectrum.

The other dimension of the matrix defines soil nutrient regime, a characteristic mainly represented by chroma. The chromas here range from $17 \%$ as assigned to the oligotrophic regime, to $100 \%$ assigned to subeutrophic and eutrophic regimes. These last two regimes are differentiated by the addition of an extra gray value to the eutrophic category.

The objective in constructing this two-dimensional color space was to separate each step by an equal number of just noticeable difference 


\section{COLOUR SCHEME FOR ECOSYSTEM UNITS}

Colours designating plant associations and subassociations on this map were selected from this matrix and modified only by addition of patterns to indicate the genetic category of soil parent material

soil nutrient regime submesotrophic subeutrophic

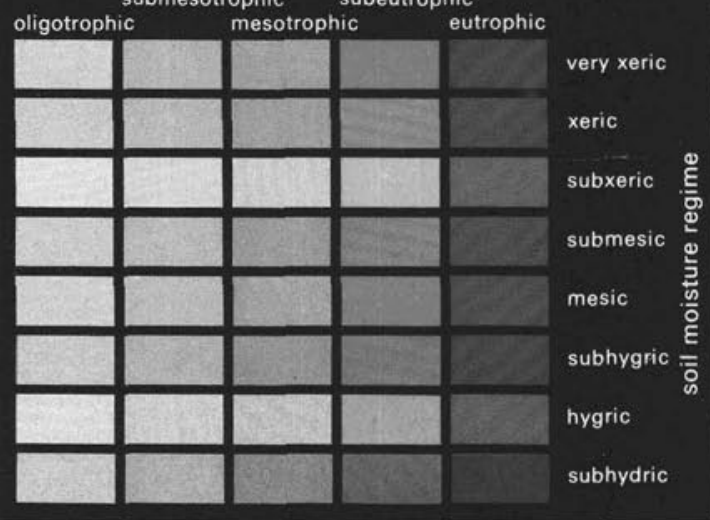

KEY TO NUMERICAL SYMBOLS

VEGETATION : SOIL PARENT MATERIAL

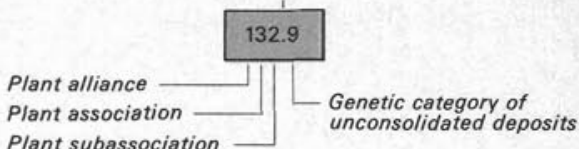

Dominant mapping unit occupying more than $50 \%$

of the area

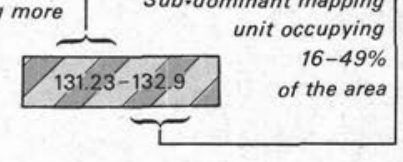

A

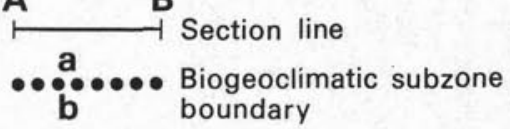

SHEET 2

(within NTS sheet $92 \mathrm{G} / 7$ )
Fig. 2. Key to the numerical symbols and color scheme.

units This then constitutes a psychological spacing rather than spacing at mathematically equal intervals. Because of time and financial constraints, the color choices in the present map represent a satisfying solution. However, further work is required to refine the color spacing and to modify certain aspects of the presentation.

To reflect priorities of the classification scheme, a texture/pattern element was added to the colors to indicate the genetic category of soil parent materials (Fig. 2). Four parent materials - glaciofluvial, glaciolacustrine, glaciomarine and organic - were assigned to patterns to test the feasibility and the effectiveness of such "pattern in the negative" symbols. We feel that the results are promising and intend further to refine the concept on subsequent projects.

The second major aspect of the presentation was a format. One of the uses envisaged for these maps was that they should function as an educational aid. This desire is reflected in the relatively small size of the sheets which facilitate easy handling in the field, and in the range and the amount of explanatory material incorporated around the margins in an attempt to make each sheet a self-contained publication.

The following criteria were also considered, metric size paper, a provision of a binding margin to enable assembly of the sheets in a folio to cover the whole forest, and a sheet designation to facilitate storing and retrieval operations. Incorporation of these criteria enable the labelling of these maps as possible prototypes for future map series.

\section{Conclusion}

The synecological classification is a natural taxonomic classification used to classify biogeocoenoses irrespective of their practical application. For management purposes there is a need to simplify technical information by grouping biogeocoenotic units into a few interpretative classes - so called treatment units (Resource Planning Division, 1976). An interpretative classification is more effective in this respect than the taxonomic classification. Similarity of vegetation-environment relationships, the tree species selection for second growth, productivity, management objectives and techniques are the criteria used to delineate the treatment units for which relatively uniform management procedures can be recommended. B.C. Forest Service is currently testing this approach and developing a design for a treatment map series at the scale $1: 20,000$.

In conclusion, it became apparent that forest management, particularly those aspects dealing with organic production, is site-specific. The synecological studies and classification can provide a comprehensive understanding of forest ecosystems. Together with the map of long lasting value it is possible to establish a sound basis on which to differentiate management practices.

\section{Acknowledgements}

We wish to acknowledge the assistance of Dr. V.J. Krajina, Department of Botany, University of British Columbia, and Mr. J. Walters, Director of the University of British Columbia Research Forest, in preparation of the map.

\section{References}

Brooke, R. C., E. B. Peterson and V.J. Krajina, 1970. The subalpine mountain hemlock zone. Ecology of Western North America, 2:147-349. 
Klinka, K. 1976. Ecosystem units - their classification, interpretation and mapping in the University of British Columbia Research Forest. Ph.D. thesis, Faculty of Forestry, University of British Columbia, Vancouver, B.C.

Kojima, Satoru and V.J. Krajina, 1975. Vegetation and environment of the Coastal western hemlock zone in Strathcona Provincial Park, British Columbia, Canada. Syesis 8 (Supplement 1): 1-123.

Krajina, V.J. 1972. Ecosystems perspectives in forestry. The H.R. MacMillan Lectureship in Forestry, 1972. Faculty of Forestry, University of British Columbia, Vancouver, B.C.

Lacate, D.S. 1965. Forest land classification for the University of British Columbia Research Forest. Forest Research Branch, Canada Dept. of Forestry Publ. No. 1107.

Lesko, G.L., 1961. Ecological study of soils in the Coastal western hemlock zone. M.Sc. thesis, Dept. Biology and
Botany, University of British Columbia, Vancouver, B.C.

Orloci, L. 1961. Forest types of the Coastal western hemlock zone. M.Sc. thesis, Dept. Botany, University of British Columbia, Vancouver, B.C.

1964. Vegetational and environmental variations in the ecosystems of the Coastal western hemlock zone. Ph.D. thesis, Dept. Botany, University of British Columbia, Vancouver, B.C.

1965. The Coastal western hemlock zone in the Southwestern British Columbia mainland. Ecology of Western N.A. 1 (1): 18-34.

Resource Planning Division, British Columbia Forest Service 1976. Planning at the sub-unit level. Discussion Paper No. 6 Victoria, B.C.

Sukachev, V.N. 1944. Principles of genetic classification in biogeocoenology. Zhurnal obshch. biol., 5 (No. 4): 213-227. Moskva.

\section{Lakehead 느 University}

\section{SCHOOL OF FORESTRY}

Applications are invited for a faculty position in the School of Forestry with a specialization in Applied Silviculture. Teaching and research in existing graduate and undergraduate programmes in silvics, silviculture and forest harvesting and reproduction methods. Twelve month renewable appointment. Ph.D. or equivalent experience in silviculture. A strong background of graduate study and field experience is desirable. Salary open and commensurate with qualifications. Benefits include retirement plan, health and life insurance, and one month paid vacation. Position currently vacant. Applications close with filling of position.

Send vitae, transcripts and names of three references to:

Mr. Donald E. Ayre,

Secretary of the University,

LAKEHEAD UNIVERSITY,

Thunder Bay, Ontario, P7B 5E1.

\section{FACULTY OF FORESTRY} UNIVERSITY OF BRITISH COLUMBIA

\section{Teaching Position Silviculture}

Rank: Open, commensurate with qualifications and experience.

Salary: Negotiable, commensurate with qualifications and experience.

Employment Date: July 1st, 1978.

Qualifications: Demonstrated teaching and research competence; Ph.D. preferred. Strong orientation towards operational silviculture desirable.

Duties: Undergraduate and graduate instruction in silvics and silviculture plus supervision of graduate research.

Closing Date: January 31st, 1978 or until position is filled.

Letter of application, full curriculum vitae, copies of important publications, and names of four references should be sent to the following person:-

\section{Dr. F. L. Bunnell, Associate Professor Faculty of Forestry \\ UNIVERSITY OF BRITISH COLUMBIA} Vancouver, B.C. V6T 1 W5 